\title{
IBM DUSUN SUKOSARI DESA PANDANSARI PONCOKUSUMO KABUPATEN MALANG
}

\author{
Sri Wahjuni Latifah ${ }^{1}$ \\ Program Studi Manajemen, Universitas Muhammadiyah Malang ${ }^{l}$
}

\begin{abstract}
Abstrak
Pengabdian masyarakat ini dilakukan di Dusun Sukosari Desa Pandansari Poncokusumo Kabupaten Malang. Dusun ini memiliki sumber daya alam yang banyak namun akibat bencana gunung Bromo tidak lagi menghasilkan sebagaimana biasanya. Perkebunan hanya mengandalkan air hujan sehingga banyak waktu yang terbuang dari para petani atau masyarakat pada umumnya. Berdasar identifikasi masalahnya ditemukan bahwa mitra memiliki pengetahuan yang rendag tentang pengelolaan sumber daya alam. Disamping itu motivasi dan pengetahuan tentang wirausaha juga rendah. Akibatnya terjadi penurunan nilai ekonomi masyarakat. Solusi yang ditawarkan adalah penyuluhan, sosialisasi dan diskusi dengan mitra. Hasilnya adalah mitra dapat memahami pengelolaan sumber daya sesuai dengan potensi dan skill masyarakat, serta mitra dapat menganalisis kelayakan usaha yang akan dikembangkan menjadi usaha bersama.
\end{abstract}

Kata kunci: bencana, poncokusumo, usaha

\section{PENDAHULUAN}

Mitra Pengabdian ini adalah masyarakat di Desa Pandansari Kecamatan Poncokusumo Kabupaten Malang. Kecamatan Poncokusumo berada di sebelah selatan Gunung Bromo dan termasuk lereng Gunung Semeru. Secara geografis termasuk dalam Kawasan Taman Nasional Bromo Tengger Semeru. yang sangat kaya akan potensi sumberdaya alam.

Pada awalnya Desa Pandansari terkenal dengan hasil perkebunan apel. Namun setelah terjadi erupsi gunung Bromo pada tahun 2016 apel tidak lagi bisa tumbuh dengan baik bahkan banyak yang kering dan mati. Saat ini matapencaharian utama penduduk desa Pandansari adalah bertani dan ada pula yang berdagang dan beternak ayam. Komoditas utamanya adalah tanaman jeruk, sebagian juga dan sayuran seperti: lombok, terong, tomat,kacang panjang, jagung dan ketela pohon. Keadaan lahan pertaniannya berada di dataran tinggi yang hanya bisa di olah dan ditanami pada musim penghujan. Namun pada musim kemarau tidak ada air, sehingga lahan tidak bisa ditanami dan tidak bisa dimanfaatkan warga.Sehingga pada musim kemarau warga banyak yang tidak bekerja atau menganggur.

Pandansari juga telah memiliki budidaya jamur tiram. Namun sampai saat ini hasil budidaya jamur tiram ini masih dijual apa adanya belum diolah lebih lanjut dan dapat memberikan tambahan nilai ekonomis. Hal ini disebabkan belum ada upaya berkesinambungan antara pemerintah setempat, petani dan masyarakat. Sehingga pengabdian yang menjadi fokus kegiatan ini adalah masyarakat yang pada musim kemarau tidak mendapatkan hasil panen dari sawah atau kebun. Untuk itu perlu memanfaatkan waktu luang dan hasil panen yang tidak terpengaruh oleh musim hujan.

\section{a. Identifikasi Masalah}

Berdasarkan musyawarah bersama dengan anggota mitra maka berikut permasalahan yang terdapat pada mitra pengabdian ini:

1. Kurangnya pengetahuan mitra dalam mengelola sumber daya alam yang sesuai dengan skill yang dimiliki.

2. Pengetahuan masyarakat tentang wirausaha sangat rendah

3. Belum ada sebuah usaha yang sesuai dengan potensi sumber daya alam dan sesuai dengan skill sumber daya manusia

\footnotetext{
1 yuni.latifah14@gmail.com
} 


\section{b. Tujuan dan manfaat kegiatan}

Tujuan kegiatan ini adalah memberikan tambahan pengetahuan kepada mitra tentang pengelolaan sumber daya alam yang baik, serta menumbuhkan motivasi wirausaha sesuai sumber dya alam yang ada dan skill dari masyarakat. Selanjutnya membangun sebuah usaha untuk mengembangkan nilai ekonomi hasil sumber daya alam supaya memiliki nilai tambah produk.

Manfaat kegiatan ini adalah: meningkatkan kesadaran dan pengetahuan warga mengenai permasalahan sumber daya alam dan pengelolaannya, meningkatkan motivasi mitra untuk berpikir dan berwawasan wira usaha. Selanjutnya mitra dapat memanfaatkan lahan dengan tidak mengandalkan musim hujan dan memanfatkan waktu luang untuk meningkatkan ekonomi melalui terbentuknya sebuah usaha.

\section{MATERI DAN METODE PELAKSANAAN}

Materi pelaksanaan program ini teridiri dari:

\section{a. Strategi Pengelolaan Sumber Daya Alam}

Seperti dikemukakan Suparmoko(1999:147), ada beberapa hal yang harus dipertimbangkan dalam mengelola sumber daya alam, yaitu: pengambilan sumber daya alam secara optimal, harga sumber daya alam,pola perkembangan produksi, pengaruh persediaan sumber daya alam, pengelolaan harus diawasi oleh seorang perencana, pengelolaan oleh seorang pesaing sempurna,perencanaan sumberdaya alam oleh monopolis, ketidakpastian pengambilan Sumber Daya Alam, ketidakstabilan di pasar Sumber Daya Alam, efisiensi, eksplorasi, distribusi dan keadilan.

\section{a. Strategi Pengelolaan Sumber Daya Manusia}

Strategi dalam pengembangan sumber daya manusia didasarkan pada Yahya \& Goh (2002) bahwa area manajemen sumber daya manusia meliputi: pelatihan, pengambilan keputusan dan penilaian kinerja. Untuk itu kegiatan ini dilakukan dengan memberikan wawasan dan pelatihan kepada mitra mengenai pengelolaan sumber daya alam serta pengetahuan dan praktik wira usaha sesuai dengan hasil sumber daya alam dan skill masyarakat mitra kegiatan ini.

\section{b. Analisis kelayakan usaha.}

Memberikan gambaran dan diskusi tentang kebutuhan investasi dan kebutuhan modal kerja serta menghitung asumsi-asumsi penjualan dan beban sehingga dapat dianalisis kelayakan usaha.

Sedangkan metode dan pendekatan yang dilakukan adalah:

a. Memberikan sosialisasi kepada masyarakat melalui kegiatan pertemuan tentang permasalahan sumber daya alam dan alternatif solusinya.

b. Memberikan penyuluhan tentang wirausaha kepada masyarakat yang menjadi mitra

c. Membentuk Usaha yang sesuai dengan potensi sumber daya alam dan sesuai dengan skill sumber daya manusia

d. Melakukan pendampingan wirausaha secara berkala dalam mengembangkan usaha tersebut dalam membentuk usaha pembuatan Kripik Singkong dan Kripik Jamur Tiram yang meliputi analisis usaha, kualitas produk, packing dengan metode simulasi, diskusi dan praktek langsung.

\section{Hasil dan Pembahasan}

Berikut hasil pelaksanaan tim dalam memecahkan permasalahan di atas

a. Kurangnya pengetahuan mitra dalam mengelola sumber daya alam yang sesuai dengan skill yang dimiliki.

Kondisi yang membuktikan bahwa mitra belum memiliki pengetahuan dalam mengelola sumber daya alam yang sesuai dengan skill yang dimiliki adalah banyaknya hasil panen seperti singkong tetapi tidak dimanfaatkan ataupun diolah lebih lanjut supaya memiliki nilai tambah. Sesudah dipanen singkong diolah dengan cara direbus atau digoreng. Demikian juga hasil panen jamur tiram juga hanya dipanen untuk dibuat sayur. Sementara itu jika diamati dari skill masyarakat terutama ibu-ibu kader PKK Desa Pandansari telah memiliki struktur yang baik. Organisasi yang terbentuk dalam PKK Desa dapat digunakan sebagai media untuk berbagi pengetahuan tentang pengelolaan sumber daya. Sebagaimana telah dibuktikan bahwa produk yang diolah lebih lanjut akan memberikan nilai tambah(value added). Sehingga dapat meningkatkan harga jual produk dan pada akhirnya dapat meningkatkan kemapuan ekonomi masyarakat. 
Hal ini telah ditemukan Alonse(2011), salah satu faktor potensial untuk memenangkan persaingan adalah diversifikasi dan pengembangan value added products.

Berdasarkan fakta tersebut maka solusi yang dilakukan adalah memberi penyuluhan pengetahuan tentang bagaimana mengelola sumber daya yang dimiliki masyarakat seperti tanah kebun yang menganggur karena musim kemarau, bagaimana mengolah hasil panen supaya memiliki nilai tambah dan dapat meningkatkan kekuatan ekonomi masyarakat. Penyuluhan dilakukan dengan mengundang kader ibu-ibu PKK serta Bapak-Bapak pengurus RT dan RW serta Kepala Dusun. Hal ini supaya pemerintah setempat juga memberi dukungan atas terlaksananya program ini. Materi penyuluhan meliputi: Pengetahuan tentang pentingnya memelihara dan mengelola sumber daya alam dengan baik. Sesuai teori yang dikemukakan Suparmoko(1999:47) ada beberapa hal yang harus dipertimbangkan dalam mengelola sumber daya alam, yaitu: pengambilan sumber daya alam secara optimal, memperhatikan harga sumber daya alam, memperhatikan pola perkembangan produksi dari hasel panen, mempeharikan pengaruh persediaan apakah mudah diperoleh atau tidak, pengelolaan sumber daya alam harus ada yang mengawasi atau harus terencana oleh pihak pemerintah minimal pemerintah desa, bagaimana jika pengelolaan sumber daya oleh pesaing sempurna atau monopolis, harus memperhatikan ketidakpastian pengambilan sumber daya alam, memperhatikan ketidakstabilan harga, jangan melakukan eksplorasi tanpa memperhatikan keberlangsungan jangka panjang dan harus melakukan distribusi sumber daya alam dengan adil.

b. Pengetahuan masyarakat tentang wirausaha sangat rendah

Pengetahuan masyarakat tentang wirausaha dapat menjadi modal untuk mendirikan usaha dari hasil pengelolaan sumber daya alam dan hasil panen sumber daya alamnya. Sebagaimana diketahui mitra pengabdian ini belum pernah memperoleh wawasan dan motivasi tentang wirausaha. Sementara jika diamati dari hasil panen singkong atau jamur tiram serta ketersediaan waktu maka mitra dapat membentuk sebuah usaha bersama yang pada akhirnya dapat meningkatkan nilai tambah produk dan nilai sumber daya ekonomi masyarakat pada umumnya. Untuk itu solusinya adalah mengubah pola pikir masyarakat menjadi pola pikir wirausaha. Dalam mengubah pola pikir mitra maka harus dipahami dulu karakteristik masyarakatnya. Sebagaimana dijelaskan di atas bahwa di Desa Pandansari telah dibentuk organisasi PKK dengan kader ibu-ibu PKK yang rutin mengadakan pertemuan. Hal ini sudah menjadi modal positif untuk mengubah pola pikir masyarakat dan mengarahkan untuk memahami sebuah usaha. Kegiatan dilakukan dengan diskusi dan sharing untuk mengevaluasi kondisi sekarang dengan kondisi yang diharapkan jika pada organisasi PKK ini memiliki sebuah uasaha. Materi yang diberikan meliputi: keuntungan-keuntungan berwirausaha yang terdiri dari keuntungan waktu maupun keuntungan ekonomi serta keuntungan berkaitan dengan pemeliharaan hasil sumber daya alam. Kegiatan pelatihan diikuti oleh pengurus kader PKK yang menjadi sasaran strategis kegiatan ini untuk selanjutnya mereka akan memberikan hasil pelatihan wira usaha ini kepada anggotanya.

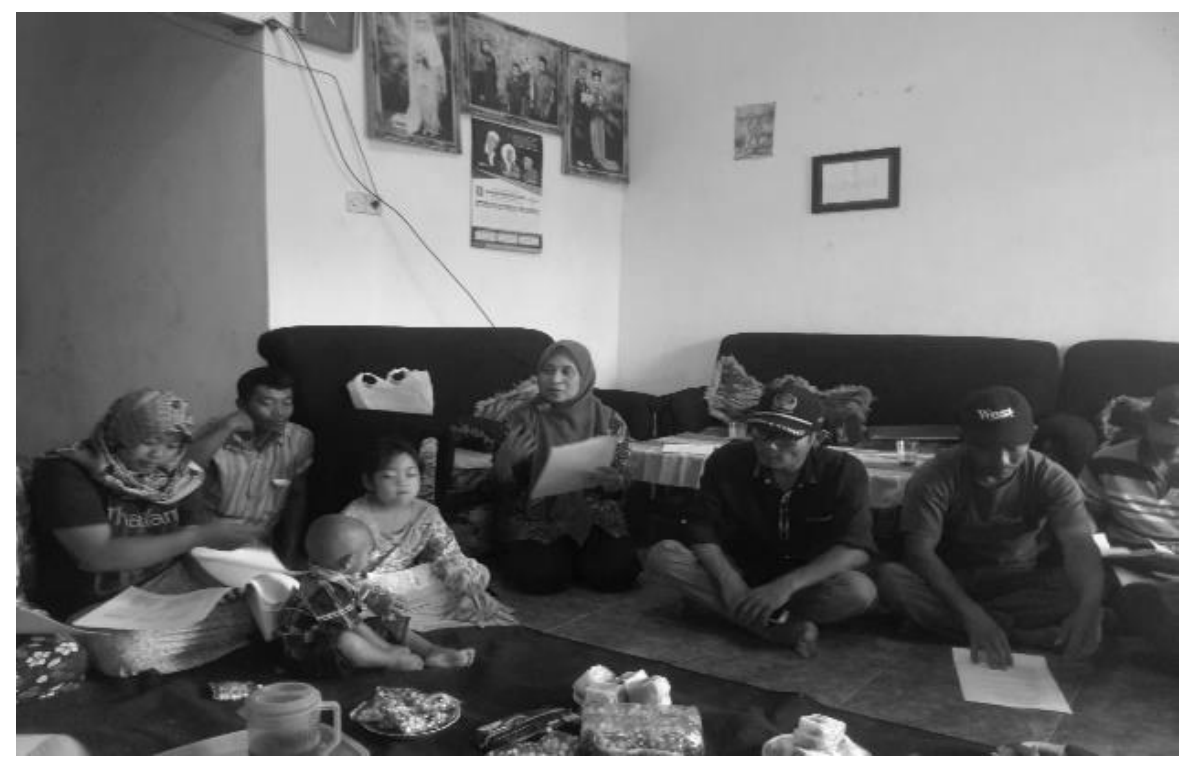

Gambar: Penyuluhan Pengelolaan Sumber Daya Alam 
c. Belum ada sebuah usaha yang sesuai dengan potensi sumber daya alam dan sesuai dengan skill sumber daya manusia.

Berdasarkan penyuluhan pengelolaan sumber daya dan motivasi wirausaha serta dilanjutkan dengan diskusi dengan mitra maka disepakati bahwa usaha yang dibentuk oleh mitra adalah Usaha Kripik singkong dan Kripik Jamur Tiram. Untuk itu dilakukan beberapa tahap mulai pelatihan meliputi analisis usaha, kualitas produk, packing dan marketing dengan metode simulasi, diskusi dan praktek langsung.

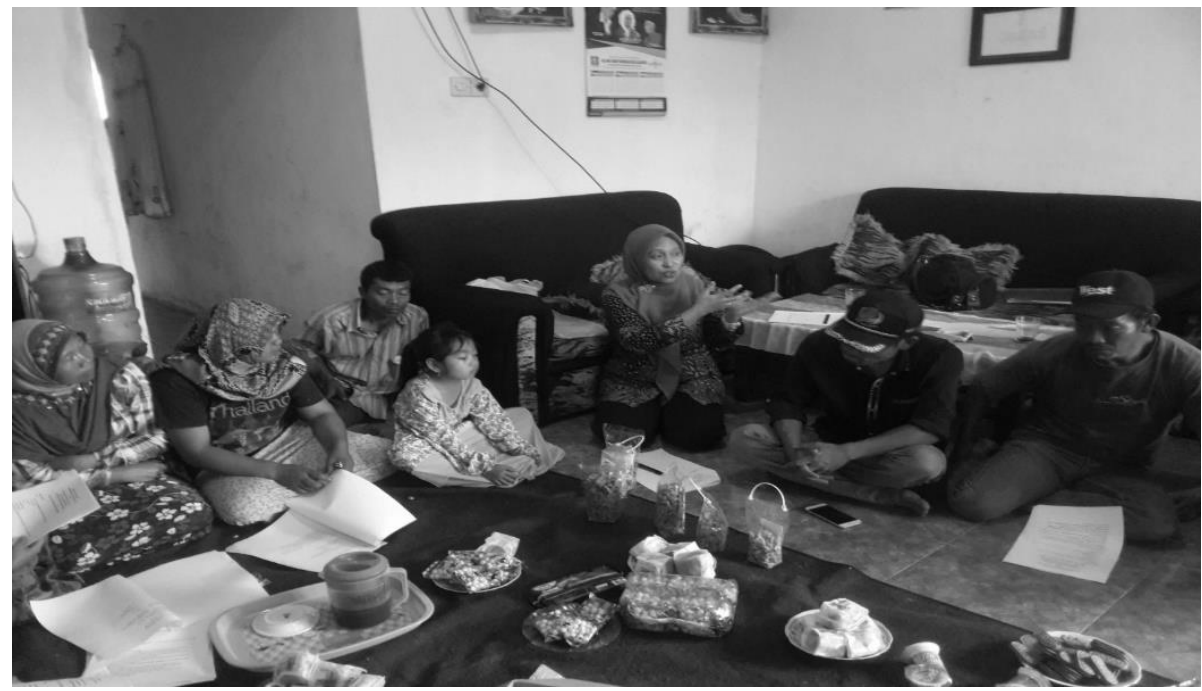

Gambar: Pelatihan produksi

Berdasarkan hasil diskusi dan simulasi tentang analisis usaha pembuatan usaha Kripik Jamur Tiram maka kebutuhan investasi meliputi: peralatan kompor, wajan, tabung gas dengan jumlah investasi sebesar Rp. 1.225.000,- Dengan asumsi usaha satu bulan dalam dua puluh lima (25) hari kerja. Maka dapat dihitung beban pokok produksi meliputi bahan dan beban tetap. Bahan yang terdiri dari jamur tiram 40 kg@Rp.13.000 sebesar Rp. 520.000, minyak goreng sebesar Rp. 160.000., bumbu dan saos sebesar Rp. 560.000, plastik kemasan sebesar Rp. 160.000, gas sebesar Rp. 60.000. Sedangkan upah tenaga kerja satu bulan satu orang dengan operasi selama 25 hari dalam satu bulan tarif upah Rp.30.000 per hari dengan demikian total upah sebesar Rp.750.000. Sedangkan beban tetapnya meliputi penyusutan peralatan sebesar Rp. 58.000,- Dengan demikian total beban pokok produksi satu(1) bulan sebesar Rp. Rp. 2.268.200. Dalam satu (1) bulan hasil penjualan jamur crispy $40 \mathrm{~kg}$ dengan harga jual kripik jamur sebesar Rp 80.000/kg sehingga total penjualan kripik jamur sebesar Rp. 3.200.000. Dengan demikian keuntungan per bulan sebesar Rp 931.800. Berdasar analisis keuangan ini maka usaha kripik jamur layak secara ekonomis karena menghasilkan cashflow positif atau mengalami keuntungan.

\section{KESIMPULAN}

Berdasarkan kegiatan pengabdian masyarakat di Desa Pandansari Kecamatan Poncokusumo Kabupaten Malang ini dapat disimpulkan bahwa sumber daya alam terutama perkebunan sudah tidak lagi memberikan hasil yang optimal akibat erusi gunung Bromo. Perkebunan apel banyak yang mati dan tanah sudah tidak lagi subur karena hanya mengandalkan air hujan. Berdasarkan analisis situasi bahwa mitra memiliki pengetahuan yang rendah tentang pengelolaan sumber daya alam, sehingga solusi yang ditawarkan adalah penyuluhan tentang pengelolaan sumber daya alam. Pengetahuan dan motivasi wirausaha juga masih rendah sehingga dilakukan sosialisasi dan motivasi wira usaha untuk mengantisipasi penurunan tingkat ekonomi pada masyarakat. Selanjutnya dilakukan pemilihan usaha bersama yang akan dibentuk oleh masyarakat khususnya pada kader ibu-ibu PKK. Usaha yang dikembangkan adalah usaha pengolahan kripik singkong dan kripik jamur tiram.

Hasil kegiatan menunjukkan bahwa mitra sudah dapat mengetahui dan memahami tentang pengelolaan sumber daya alam yang sesuai dengan skill masyarakat. Mitra pengabdian ini telah memperoleh penimgkatan wawasan tentang wirausaha serta telah dapat mengembangkan sebuah usaha bersama yaitu usaha kripik singkong dan kripik jamur. Disamping itu mitra dapat melakukan pembuatan 
produk dan dapat menganalisis kelayakan usaha.

\section{UCAPAN TERIMAKASIH}

Dengan terselesainya kegiatan pengabdian ini, maka kami sampaikan terimakasih yang sebesarbesarnya kepada Rektor Universitas Muhammadiyah Malang, Dekan Fakultas Ekonomi \& Bisnis, beserta jajarannya yang telah memberikan dana kegiatan ini sehingga dapat selesai dengan lancar dan tak kurang satu apapun. Terimakasih juga untuk Solikhul sebagai Kepala Dusun Sukosar Desa Pandansari Kecamatan Poncokusumo Kabupaten Malang serta ibu-ibu kader PKK yang telah membantu dan mendukung kegiatan ini.

\section{REFERENSI}

Alonse, Abel Duarte,2011," Muscadines, wineries and Value added products: an exploratory study", British Journal, vol 113, no3

Suparmoko(1999:47) Ekonomi Sumber Daya Alam dan Lingkungan, edisi 2, BPFE UGM Studi Kelayakan....

Sumodiningrat,G, 1997,'Pembangunan Daerah dan Pemberdayaan Masyarakat'Bina Rena Pariwara Jakarta

Sumodiningrat, G, 1999'Pemberdayaan masyarakat dan Jaring Pengaman Sosial" Gramedia Jakarta

Suparmoko, 1999, Ekonomi Sumber Daya Alam dan Lingkungan, edisi 2, BPFE

Yahya \&Goh,2002, Managing human resources toward achieving knowledge management. Journal of Knowledge Management. 6(5). 457-468. 
